\title{
Correlation between type 2 diabetes mellitus and central corneal thickness: A cross-sectional study
}

\author{
Desai J. ${ }^{1 *}$
}

DOI: https://doi.org/10.17511/jooo.2021.i02.03

1* Jigish Desai, Associate Professor, Department of Ophthalmology, Banas Medical College and Research Institute, Palanpur, Gujarat, India.

Background and Aim: Diabetes has emerged as an important global health concern because of its various adverse effects on the ocular tissue. The present study was done to study the correlation between type 2 diabetes mellitus and central corneal thickness in patients coming to the tertiary care institute of Gujarat, India. Material and Methods: The present study was conducted over 1 year at the tertiary care institute of Gujarat, India.50 patients with type 2 diabetes mellitus previously diagnosed by a physician on treatment and 50 age-matched controls who are nondiabetics on history and blood sugar levels were enrolled. The central corneal thickness was measured using an ultrasound pachymeter using multiple reading single point modes by a single person. Results: The mean central corneal thickness in diabetics was $565 \pm 21$ micrometres and in non-diabetics was $517 \pm 20$ micrometres. The central corneal thickness was found to be higher in patients with type 2 diabetes mellitus when compared to non-diabetics. Conclusion: Patients with type 2 diabetes mellitus were found to have thicker corneas as compared to non-diabetics. This should take into consideration while interpreting intraocular pressure and before any refractive surgeries in diabetics.

Keywords: Central Corneal Thickness, Diabetes Mellitus, Intraocular Pressure, Ultrasound pachymeter

Corresponding Author

Jigish Desai, Associate Professor, Department of Ophthalmology, Banas Medical College and Research Institute, Palanpur, Gujarat, India.

Email: researchguide86@gmail.com

\section{How to Cite this Article}

Desai J, Correlation between type 2 diabetes mellitus and central corneal thickness: A cross-sectional study. Trop J Ophthalmol Otolaryngol. 2021;6(2):3539.

Available From

https://opthalmology.medresearch.in/index.php/jooo /article/view/193
To Browse

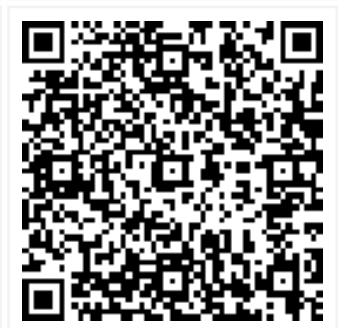

Manuscript Received 2021-04-02

Conflict of Interest No

Review Round 1
2021-04-12
Funding
Nil

2021 by Jigish Desai and Published by Siddharth Health Research and Social Welfare Society. This is an Open Access article
licensed under a Creative Commons Attribution 4.0 International License https://creativecommons.org/licenses/by/4.0/

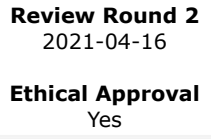

Review Round 3

Accepted 2021-04-19

Note 


\section{Introduction}

Diabetes mellitus is a syndrome characterized by inappropriate hyperglycemia and is chronically associated with microvascular and macrovascular complications. Patients with diabetes mellitus often develop not only diabetic retinopathy but also corneal endothelial damage and keratoepitheliopathy such as superficial punctate keratitis, recurrent corneal erosion, and persistent epithelial defects $[1,2]$.

The main indicators of diabetes in ocular tissues are retinopathy, cataract and glaucoma The corneal changes associated with Diabetes mellitus is known as diabetic keratopathy, a lesser-studied pathology [3]. It can have varied presentations like decreased corneal sensitivity, epithelial disorders like superficial punctate keratitis and epithelial erosions, thickened basement membrane [4,5]. Increased serum levels of glycosylated haemoglobin increase the predisposition to impaired corneal epithelial barrier function.

Glucose can act as a collagen cross-linking agent with the help of advanced glycosylation end products. Advanced millard products accumulate in collagen proteins result in the formation of covalent cross-linking bonds and may lead to increased corneal thickening and biochemical changes [6].

Increased serum levels of glycosylated haemoglobin predispose impairment of corneal epithelial barrier function [7]. Glucose can form collagen cross-links with the help of advanced glycosylated end products.

They increase covalent bond in corneal stroma which may lead to increased corneal thickness [8]. According to some studies intracellular accumulation of sorbitol which acts as an osmotic agent causes corneal hydration. Reduction of $\mathrm{Na}+\mathrm{K}+$ ATPase activity inhibits the corneal endothelial pump and can also cause increased corneal thickness.

The corneal endothelium in diabetic patients is considered as tissue under continuous metabolic stress and it has increased coefficient of variation of endothelial cell area, decreased percentage of hexagonality and increased corneal autofluorescence $[9,10]$.

The central corneal thickness is a sensitive indicator of the health of the cornea and serves as an index for corneal hydration and metabolism.
It is also an important indicator of patency of corneal endothelium pump and can be objectively measured by the variety of techniques like optical pachymetry, ultrasound pachymetry, confocal microscopy, ultrasound biomicroscopy, optical ray path analysis or scanning slit corneal topography and optical coherence tomography [11]. Ultrasound pachymetry is the current standard for corneal thickness measurement [12].

The present study was done to study the correlation between type 2 diabetes mellitus and central corneal thickness in patients coming to the tertiary care institute of Gujarat, India.

\section{Material and Methods}

\section{Study Setting}

The present study was conducted for 1-year at the tertiary care institute of Gujarat, India.

\section{Ethical Consideration and Permission}

Ethical approval was taken from the institutional ethical committee and written informed consent was taken from all the participants.

\section{Inclusion criteria}

50 patients with type 2 diabetes mellitus previously diagnosed by a physician on treatment and 50 agematched controls who are non-diabetics on history and blood sugar levels were enrolled.

\section{Exclusion criteria}

01. Corneal dystrophies. 2. Contact lens users. 3. Ocular surface disorders. 4. History of previous ocular surgeries. 5. History of use of ocular medications.

\section{Methodology}

Routine ophthalmic examination was done in all patients. The central corneal thickness was measured using an ultrasound pachymeter using multiple reading single point modes by a single person. Average of 5 consecutive readings with a standard deviation less than $0.005 \mathrm{~mm}$ was taken as the final reading.

\section{Statistical analysis}

The recorded data was compiled and entered in a spreadsheet computer program (Microsoft Excel 2007) and then exported to the data editor page of SPSS version 15 (SPSS Inc., Chicago, Illinois, USA). For all tests, confidence level and level of significance were set at $95 \%$ and $5 \%$ respectively. 


\section{Results}

The mean age of the study population was $50.5 \pm$ 5.5 years. $38.5 \%$ of the subjects in both casecontrol groups were in the age group of 50 to 59 years.54\% were males and $46 \%$ were females. (Table 1)The mean central corneal thickness in diabetics was $565 \pm 21$ micrometres and in nondiabetics was $517 \pm 20$ micrometres. (Table 2)The central corneal thickness was found to be higher in patients with type 2 diabetes mellitus when compared to non-diabetics. The difference between the cases and the control group was found to be statistically significant ( $p$-value $<0.05$ ).

Table 1: Gender wise distribution of study participants

\begin{tabular}{|c|c|c|}
\hline Gender & $\mathbf{N}$ & Percentage $(\%)$ \\
\hline Male & 54 & 54 \\
\hline female & 46 & 46 \\
\hline
\end{tabular}

Table 2: Mean central corneal thickness in cases and control

\begin{tabular}{|l|c|l|l|}
\hline \multicolumn{1}{|c|}{ Subjects } & N & \multicolumn{1}{|c|}{ Mean CCT $(\boldsymbol{\mu})$} & \multicolumn{1}{c|}{ SD $( \pm)$} \\
\hline Diabetics & 50 & 565 & 21 \\
\hline Non-Diabetics & 50 & 517 & 20 \\
\hline
\end{tabular}

\section{Discussion}

Lifestyle changes have led to an increase in the incidence of diabetes worldwide. Diabetic keratopathy implies a spectrum of changes occurring in the cornea of diabetic patients. The central corneal thickness of diabetics is thicker than that of normal persons due to morphological changes of the diabetic cornea $[13,14]$. Some experimental studies using mice or dogs reported a decrease in the corneal endothelium density, a decrease in hexagonality, and an increase in the coefficient of variation for cell size in the case of diabetes [15]. Lee et al [16] showed that diabetics with $\geq 10$ years duration have more corneal morphological abnormalities compared with the normal subjects and the central corneal thickness was significantly correlated with diabetic duration after controlling for age. Keolain et al [17]. reported that diabetics frequently had abnormal corneal endothelium in contrast to normal persons, but there were no significant differences in terms of the function of the fluorescence permeability of the corneal thickness and endothelium. This means that the corneal endothelium of diabetics has a structural disorder, but the functional disorder of the corneal tissues is not affected.
In our study, we found that patients with Type 2 Diabetes Mellitus have a greater average central corneal thickness than non-diabetics. A study conducted by Ozdamar $Y$, et al. showed that mean CCT in diabetics $(564 \pm 30 \mu)$ was higher compared with the control group $(538 \pm 35 \mu)(P=0.001)$ [18]. Claramonte $\mathrm{PJ}$, et al. conducted a study to prove the correlation between central corneal thickness and diabetes. Ultrasound pachymetry measurements were made and the average central corneal thickness in diabetic patients was $570.48 \pm 21.72 \mu$ and in non-diabetics was $543.49 \pm 34.21 \mu$ [19].

Lee et al. studied the effect of duration of diabetes on corneal thickness and reported that diabetic patients with a duration of $>10$ years have more corneal morphological abnormalities as compared to non-diabetics [20]. Mc Namara et al. reported that there was a positive correlation between HbA1c levels in type 2 diabetes [21]. McNamara et al observed a positive correlation between $\mathrm{HbA} 1 \mathrm{c}$ level and CCT in Type 1 diabetics but reported thicker corneas in diabetics but found no direct correlation with $\mathrm{HbA1c}$ level in type 2 diabetes similar to our study.21 This observation was reinforced by Yasgan $S$ et al [22].

Thicker central cornea associated with diabetes mellitus should be taken into consideration while obtaining accurate intraocular pressure measurements in diabetics

\section{Conclusion}

Patients with type 2 diabetes mellitus were found to have thicker corneas as compared to non-diabetics. This should take into consideration while interpreting intraocular pressure and before any refractive surgeries in diabetics.

Measuring CCT in diabetic patients should be mandatory especially in preoperative workup of refractive surgery, for donor tissue evaluation before keratoplasty, glaucoma suspects, long term contact lens users etc. This may help to identify patients at higher risk of developing severe complications thus enabling the ophthalmologist to treat their disease more accurately.

\section{What does this study add to existing knowledge?}

Diabetes has emerged as an important global health concern because of its various adverse effects on the ocular tissue. 
A significant correlation was found between increase CCT and diabetes, with a positive correlation between the thick cornea and the duration of diabetes, indicating that patients with thick corneas are more likely to be found in an advanced stage of the disease. Measurement of CCT complemented with the study of the corneal endothelium can provide further insight for the proper evaluation of this patient regarding their functional outcome. As the basic histopathological change is the formation of covalent bonds in the corneal stroma, the study of the relation between diabetic keratopathy and the corneal ectatic condition is warranted.

\section{Reference}

01. Su DH, Wong TY, Wong WL, Saw SM, Tan DT, Shen SY, et al. Diabetes, hyperglycemia, and central corneal thickness- the Singapore Malay Eye Study. Ophthalmology. 2008 Jun;115(6)964-968.

e1. doi: 10.1016/j.ophtha.2007.08.021 [Crossref]

02. Ozdamar Y, Cankaya B, Ozalp S, Acaroglu G, Karakaya J, Ozkan SS. Is there a correlation between diabetes mellitus and central corneal thickness?. J Glaucoma. 2010 Dec;19(9)613-6. doi: 10.1097/IJG.0b013e3181ca7c62 [Crossref]

03. Schwartz DE. Corneal sensitivity in diabetics. Arch Ophthalmol. 1974 Mar;91(3)174-8.

doi: $\quad 10.1001 /$ archopht.1974.03900060182003 [Crossref]

04. Gekka M, Miyata K, Nagai Y, Nemoto S, Sameshima T, Tanabe T, et al. Corneal epithelial barrier function in diabetic patients. Cornea. 2004 Jan;23(1)35-7.

doi: 10.1097/00003226-200401000-00006 [Crossref]

05. Naumann GOH, Holbach L, Kruse FE. Apliedpathologyfor ophthalmic microsurgeons. Springer-verlag Berlin Heidelberg NewYork. 2008; Germany 351.

[Crossref]

06. Sahin A, Bayer A, Ozge G, Mumcuoğlu T. Corneal biomechanical changes in diabetes mellitus and their influence on intraocular pressure measurements. Invest Ophthalmol Vis Sci. 2009 Oct; 50(10)4597-604.

doi: 10.1167/iovs.08-2763 [Crossref]
07. Schwartz DE. Corneal sensitivity in diabetics. Arch Ophthalmol. 1974 Mar;91(3)174-8.

doi: $\quad$ 10.1001/archopht.1974.03900060182003 [Crossref]

08. Gekka M, Miyata K, Nagai Y, Nemoto S, Sameshima T, Tanabe T, et al. Corneal epithelial barrier function in diabetic patients. Cornea. 2004 Jan;23(1)35-7.

doi: 10.1097/00003226-200401000-00006 [Crossref]

09. Roszkowska AM, Tringali CG, Colosi P, Squeri $C A$, Ferreri G. Corneal endothelium evaluation in type I and type II diabetes mellitus. Ophthalmologica. $1999 ; 213(4) 258-61$. doi: $10.1159 / 000027431$ [Crossref]

10. Keoleian GM, Pach JM, Hodge DO, Trocme SD, Bourne WM. Structural and functional studies of the corneal endothelium in diabetes mellitus. Am J Ophthalmol. 1992 Jan 15;113(1)64-70. doi: 10.1016/s0002-9394(14)757551 [Crossref]

11. Yaylali V, Kaufman SC, Thompson HW. Corneal thickness measurements with the Orbscan Topography System and ultrasonic pachymetry. J Cataract Refract Surg. 1997 Nov;23(9)134550.

doi: $10.1016 / \mathrm{s} 0886-3350(97) 80113-7$ [Crossref]

12. Salz JJ, Azen SP, Berstein J, Caroline $P$, Villasenor RA, Schanzlin DJ. Evaluation and comparison of sources of variability in the measurement of corneal thickness with ultrasonic and optical pachymeters. Ophthalmic Surg. 1983 Sep;14(9)750-4.

[Crossref]

13. Williams $R$, Airey $M$, Baxter $H$, Forrester $J$, Kennedy-Martin T, Girach A. Epidemiology of diabetic retinopathy and macular oedema- a systematic review. Eye (Lond). 2004 Oct; $18(10) 963-83$.

doi: $10.1038 /$ sj.eye.6701476 [Crossref]

14. Claramonte PJ, Ruiz-Moreno JM, Sánchez-Pérez SI, León M, Griñó C, Cerviño VD, et al. Variation of central corneal thickness in diabetic patients as detected by ultrasonic pachymetry. Arch Soc Esp Oftalmol. 2006 Sep;81(9)523-6. doi: $10.4321 /$ s0365-66912006000900007 [Crossref] 
15. O'Donnell C, Efron N. Corneal endothelial cell morphometry and corneal thickness in diabetic contact lens wearers. Optom Vis Sci. 2004 Nov;81(11)858-62.

doi: $\quad 10.1097 / 01.0 p x .0000145029 .76675 . f 7$ [Crossref]

16. Lee JS, Oum BS, Choi HY, Lee JE, Cho BM. Differences in corneal thickness and corneal endothelium related to duration in diabetes. Eye (Lond). 2006 Mar;20(3)315-8.

doi: $10.1038 /$ sj.eye.6701868 [Crossref]

17. Keoleian GM, Pach JM, Hodge DO, Trocme SD, Bourne WM. Structural and functional studies of the corneal endothelium in diabetes mellitus. Am J Ophthalmol. 1992 Jan 15;113(1)64-70.

doi: $10.1016 /$ s0002-9394(14)757551 [Crossref]

18. Ozdamar Y, Cankaya B, Ozalp S, Acaroglu G, Karakaya J, Ozkan SS. Is there a correlation between diabetes mellitus and central corneal thickness?. J Glaucoma. 2010 Dec;19(9)613-6.

doi: $10.1097 /$ IJG.0b013e3181ca7c62 [Crossref]
19. Claramonte PJ, Ruiz-Moreno JM, Sánchez-Pérez SI, León M, Griñó C, Cerviño VD, et al. Variation of central corneal thickness in diabetic patients as detected by ultrasonic pachymetry. Arch Soc Esp Oftalmol. 2006 Sep;81(9)523-6. doi: $10.4321 /$ s0365-66912006000900007 [Crossref]

20. Lee JS, Oum BS, Choi HY, Lee JE, Cho BM. Differences in corneal thickness and corneal endothelium related to duration in diabetes. Eye (Lond). 2006 Mar;20(3)315-8. doi: 10.1038/sj.eye.6701868 [Crossref]

21. McNamara NA, Brand RJ, Polse KA, Bourne WM. Corneal function during normal and high serum glucose levels in diabetes. Invest Ophthalmol Vis Sci. 1998 Jan;39(1)3-17.

[Crossref]

22. Yazgan S, Celik U, Kaldırım H, Ayar O, Elbay A, Aykut $V$, et al. Evaluation of the relationship between corneal biomechanic and HbA1C levels in type 2 diabetes patients. Clin Ophthalmol. 2014 Aug 19;8;1549-53.

doi: $10.2147 /$ OPTH.S67984 [Crossref] 